\title{
Continuing teachers education and social learning in the promotion of geoconservation: the case of the Gold Cycle Geopark Project, Guarulhos, São Paulo, Brazil
}

\author{
Diogo B. Soares ${ }^{1}$, Vânia M. N. Santos ${ }^{2}$ \\ 1 - Graduate Program of Teaching and History of Earth Sciences, P0 Box 6152, 13083-855 Campinas, SP, Brazll. E-mall: diogosoares@ige.unicamp.Br \\ 2 - Graduate Program of Teaching and History of Earth Sciences, P0 Box 6152, 13083-855 Campinas, SP, Brazll. E-mall: vanianunes@ige.unicamp.br
}

Abstract: This article aims to present possibilities of the use of participatory methodologies, such as Social Learning tools, in the promotion of geoconservation. The reflections presented here were built upon "Module III - Social Learning" of the continuing education course for teachers "Education, Environment and Social Learning: socio-educational practices for sustainability and geoconservation", developed in the city of Guarulhos, São Paulo, Brazil. The course was promoted within the scope of the Gold Cycle Geopark Project and its results subsidized a postdoctoral research, a master's research, specialized publications in the area, and contributions to Education for Geoconservation. The methodological proposal was based on five public schools in Guarulhos and involved teachers from different areas of knowledge. In addition to the pedagogical and management teams of the schools, different social actors took part in the initiative, such as: representatives of the community, partner universities and municipal secretariats of the city. The main objective of the course was to develop collaborative socio-environmental proposals for the promotion of citizenship, sustainability and protection of local geoheritage by the school.

\section{Manuscript:}

Received: Quadrennial Conference of the International Geoscience Education Organization Accepted: 14/01/2018

Citation: Soares D.B., Santos V.M.N. 2018. Continuing teachers education and social learning in the promotion of geoconservation: the case of the Gold Cycle Geopark Project, Guarulhos, São Paulo, Brazil. Terræ Didatica, 14(4):373-378. URL: http://www.ige.unicamp.br/terraedidatica/.

Keywords: Geosciences education, social learning, participatory methodologies, geopark.

Thematic line: Geoconservation, Geotourism and Geoheritage.

\section{Introduction}

The present article introduces possibilities of the use of participative methodologies, such as: socio-environmental mapping (Santos 2006, Santos 2011, Santos \& Bacci 2011), role-playing games (Marcatto 1996, Pavão 2000, Riyis 2004, Camargo 2006, Amaral 2008, Amaral \& Bastos 2011), Worldcafé (Brown \& Isaacs 2007, Camargo 2011, 2015), in the promotion of geoconservation.

Participatory methodologies are tools of Social Learning that allow the establishment of dialogue, cooperation and consensus among different stakeholders. Social Learning is the basis for the learning of environmental citizenship and, therefore, for the incorporation of individual and collective attitudes towards local sustainability (Jacobi 2011, p.16).

If, on the one hand, Social Learning allows us to use participatory tools aimed at social mobilization, on the other hand, Geosciences, due to their interdisciplinary nature and their holistic, systemic and historical view of nature (Potapova 1968, Paschoale 1989, Brusi 1992, Frodeman 2010, Orion 2011, Compiani 2013). This allows the understanding of the dynamics of the Earth System and, from this understanding, reconcile the proposition of transformative local actions that are capable of generating interaction between the environment and society.

According to Soares \& Santos (2014), the dialogue between Earth Sciences and Social Sciences is fundamental for understanding the complexity that surrounds geoparks in urban areas. Therefore, it is necessary to develop educational actions based on collaborative dynamics that have as a main objective the heritage and environmental valorization, to promote sustainability and local geoconservation. Thus, participatory methodologies collaborate to rethink the educational practices that involve environmental education and the teaching of Earth Sciences.

As a geoscientific territory that considers the different local stakeholders for the promotion of educational, tourist and / or educational activities, the geopark concept dialogues with the assumptions of Social Learning, which, according to Cernesson et al. (2005), means 'learning together to manage together.'

From this perspective, with the Geopark Gold Cycle Project as a locus, the continuing education 
course for teachers "Education, Environment and Social Learning: socio-educational practices for sustainability and geoconservation" was developed. The main objective of the methodological proposal was to develop, together with five state public schools in the region, collaborative socioenvironmental proposals for the promotion of citizenship, sustainability and protection of local heritage.

\section{The Gold Cycle Geopark Project}

The Gold Cycle Geopark Project is so named because it is not yet part of the Global Geoparks Network, established in 2004 through a partnership between the United Nations Educational, Scientific and Cultural Organization (UNESCO) and the International Union of Geological Sciences (IUGS). The Project is one of the proposals for the creation of new geoparks in Brazil, coordinated by Companhia de Pesquisa de Recursos Minerais (CPRM) (Schobbenhaus \& Silva 2012).

Perez-Aguilar et al. (2012) explain that the process of structuring the Gold Cycle Geopark Project, in Guarulhos, began with Decree $n^{\circ}$. 25,491 of June 9, 2008 of the Municipality of Guarulhos, whereby the Executive instituted a working group aimed at the implementation and management of the Unidade de Conservação Parque Natural Municipal da Cultura Negra Sítio da Candinha, and at establishing guidelines for the structuring of this geopark.

This group was constituted by representatives of public, religious, educational, NGOs and civil society sectors, promoting discussions in a multidisciplinary scope. The work developed allowed the listing of significant components, which culminated in the creation of the Geopark by Municipal Decree of Guarulhos $n^{\circ} .25 .974$ of December 16, 2008 (Fig. 1).

The site presents historical, archaeological, biological, geological, scenic and tourist attributes, mapped and recognized by the municipality. These attributes are inserted in a complex context, since the Gold Cycle Geopark Project is characterized as an urban geopark, established in a municipality of approximately 1,324,781 inhabitants (Census 2010), belonging to the Metropolitan Region of São Paulo. The numerous socio-environmental challenges of Guarulhos reflect the difficulty of implementing, managing and disseminating the potentialities of the Geopark (Soares \& Santos 2014, Soares 2016, Soares \& Santos 2017).

\section{GEOPARQUE CICLO DO OURO}

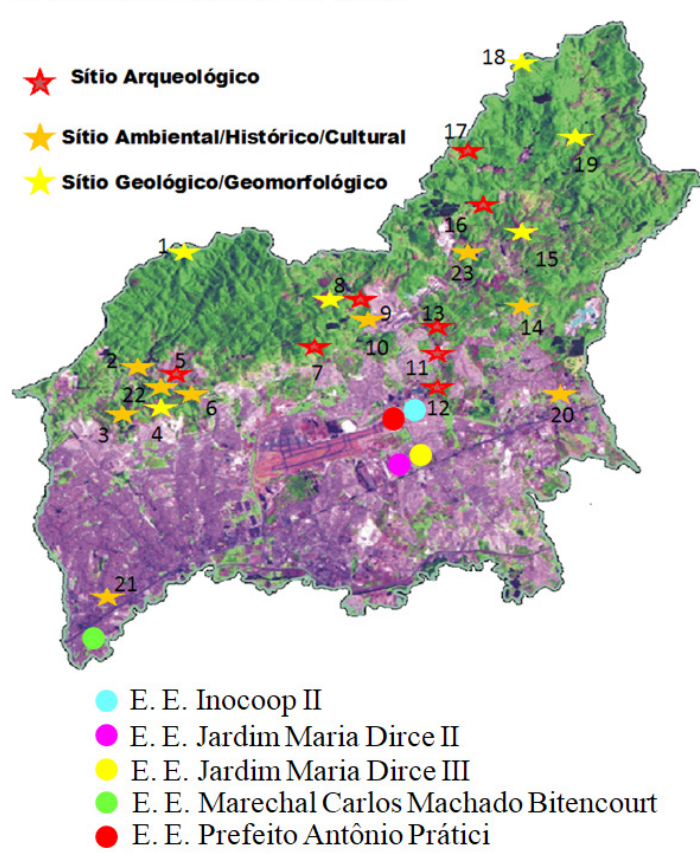

Figure 1. Geographical delimitation and sites of interest of the Gold Cycle Geopark Project (Source: Socioenvironmental Diagnosis of the Gold Cycle Geopark Project, Guarulhos and guidelines for its implementation, Perez-Aguilar et al. 2012)

\section{The Continuing Education Teacher Training Course}

The selection of schools for the development of the continuing education teacher training proposal, focused on the study of geodiversity sites in Guarulhos, took into account their interest in participating (Soares 2016). Although some schools were not very close to the study sites, they already had a history of participation in the projects of continuing education of teachers, promoted by the Municipality of Guarulhos, including "School Citizenship Nuclei" (Santos 2006, 2011). With the participation of the Board of Education of Guarulhos Sul, five schools were selected in the southern region of the Municipality, namely:

- Public State School Inocoop II;

- Public State School Jardim Maria Dirce II;

- Public State School Jardim Maria Dirce III;

- Public State School Marechal Carlos Machado Bitencourt (Núcleo de Cidadania);

- Public State School Prefeito Antônio Prátici (Núcleo de Cidadania). 
The contents of the course were divided into three parts: thematic block I - Education, thematic block 2 - Environment, and thematic block 3 Social Learning (Tab. 1).

The continuing education teachers education course took place through a partnership between the Prefeitura Municipal de Guarulhos (Serviço Autônomo de Água e Esgoto, Secretaria de Meio Ambiente, Secretaria de Desenvolvimento Econômico/Departamento de Turismo, Secretaria da Educação); Laboratório de Pesquisa e Prática em Educação e Sustentabilidade da Universidade de São Paulo (LAPPES/USP); Núcleo de Apoio à Pesquisa em Patrimônio Geológico e Geoturismo do Instituto de Geociências da Universidade de São Paulo (NAP GeoHereditas/IGc/USP); Instituto Geológico do Estado de São Paulo (IG); Universidade de Guarulhos (UnG); and Diretoria de Ensino Guarulhos Sul. The initiative also had the support of the Organização Eco Social Água Azul, Centro de Educação Ambiental da Água Azul, Seminário Diocesano Imaculada Conceição, and Ambev - filial Guarulhos (Soares 2016, Santos \& Jacobi 2017, Soares \& Santos 2017).

Both the process and the course products (collaborative socio-environmental school proposals as contributions to Geoconservation and Sustainability) were analyzed in a postdoctoral research carried out at the Instituto de Energia e Ambiente da Universidade de São Paulo (Santos 2015), and also by a Master's degree, defended at the Instituto de Geociências da Universidade Estadual de Campinas (Soares 2016), where the Doctoral advisor and doctoral student, are authors of the present work.

\section{Participatory Methodologies for the Promotion of Geoconservation}

Participatory practices within the course were carried out with teachers, students, trainers, members of the public sector and representatives of the local community.

\subsection{Socio-environmental Mapping}

According to Santos \& Bacci (2011), socioenvironmental mapping is a didactic-pedagogical instrument of diagnosis, planning and action that promotes the participation of the local community in the collection of different information about the place, using maps, aerial photographs or satellite images and field trips.

Socio-environmental Mapping makes it possible to know the place and its problems, as well as to share knowledge, experiences and perceptions about the socio-environmental reality.

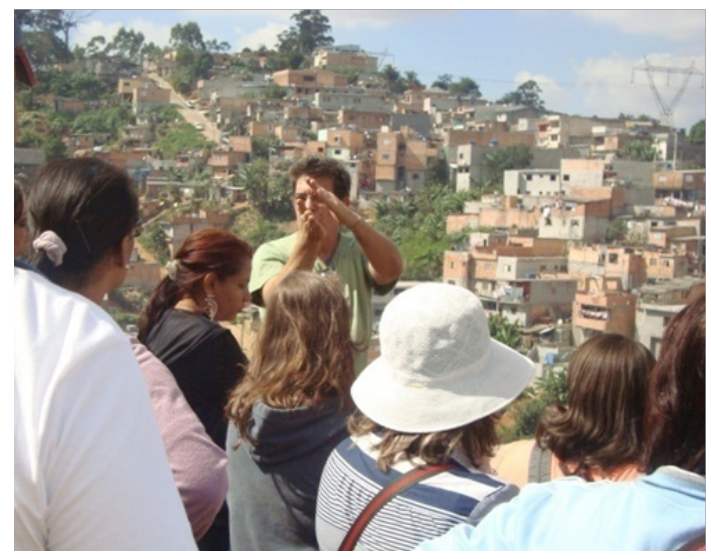

Figure 2. Socio-environmental mapping carried out in the Marundito do Pico Pelado Geosite (Soares 2016, Soares \& Santos 2017)

Table 1. Modules, objectives and methodologies worked on the course of continuing teacher training

\begin{tabular}{l|l|l}
\hline $\begin{array}{l}\text { Thematic } \\
\text { Blocks }\end{array}$ & Modules & Methodologies \\
\hline I. Education & $\begin{array}{l}\text { a. School and Socio-environmental Issues: socio-political-peda- } \\
\text { gogical reflections. } \\
\text { b. School and construction of local environmental knowledge. } \\
\text { c. Pedagogical dialogues: reflections on knowledge and school } \\
\text { practices. }\end{array}$ & $\begin{array}{l}\text { Practical and expositive classes } \\
\text { on the role of the teacher and } \\
\text { the school in the development } \\
\text { of socio-environmental pro- } \\
\text { jects for the community. }\end{array}$ \\
\hline $\begin{array}{l}\text { II. Environ- } \\
\text { ment }\end{array}$ & $\begin{array}{l}\text { a. Sustainability and Geoconservation: the Gold Cycle Geopark } \\
\text { Project. } \text { Environmental Trails in Guarulhos. } \\
\text { c. Socio-environmental mapping. }\end{array}$ & $\begin{array}{l}\text { Field activities to places of } \\
\text { interest in the Gold Cycle } \\
\text { Geopark Project. }\end{array}$ \\
\hline $\begin{array}{l}\text { III. Social } \\
\text { Learning }\end{array}$ & $\begin{array}{l}\text { a. Education and Social Learning. } \\
\text { b. Participatory methodologies in education for sustainability. } \\
\text { c. Social and environmental collaborative projects }\end{array}$ & Participatory methodologies. \\
\hline
\end{tabular}

\begin{tabular}{c|c|c|c|c|c}
\hline \multicolumn{1}{|c|}{ Terrae Didat. } & Campinas, SP & v.14 & n.4 & p. 371-376 & out./dez. 2018 \\
\hline
\end{tabular}


The activity objectives were to promote dialogue and reflection on the socio-environmental reality of the Marundito do Pico Pelado Geosite (Fig. 2), considering the different points of view and interests of the different stakeholders, besides proposing actions to promote geoconservation and sustainability. The activity gave rise to the propositional map-synthesis of the site (Fig. 3).

\subsection{Role-Playing Game: Stakeholders Game}

The Role-playing Game, better known as RPG, is a type of game in which players assume fictional roles and create narratives collaboratively through a hypothetical scenario in order to reach a consensus to solve a problem question. In the Portuguese translation, RPG would mean something like "Game of Interpretations" or "Game of Representations".

According to Marcatto (1996), RPG has the potential to improve social relations in school. According to the author, this methodology began to be used in the educational area, more specifically in the teaching of Sciences, due to its playful potential.

The purpose of the Role-Playing Game was to understand the complex context in which the Marundito do Pico Pelado Geosite is inserted, and to recognize the role and importance of dialogue between different stakeholders (teachers, technical professionals, biologists, geologists, historians, sociologists, etc.) for the promotion of Geoconservation and Sustainability at the site (Fig. 4).

\subsection{World-Café}

The World-Café held with teachers can be defined as a metaphor of a collective learning that is constituted from the exchange of knowledge and shared knowledge, as a living system of conversation that stimulates the collective creation of new scenarios of change and socio-environmental transformation.

The principles of these methodologies are found in conversational practices that recover the sense of community, in a dialogue that seeks the full involvement of the participants, the collective intelligence that emerges from the group and the collective creation of solutions to complex problems (Camargo 2011, 2015). That is the reason why Brown \& Isaacs (2007) state that when people talk and share their point of view with others, everyone becomes able to access a greater wisdom that is found only in the collective.

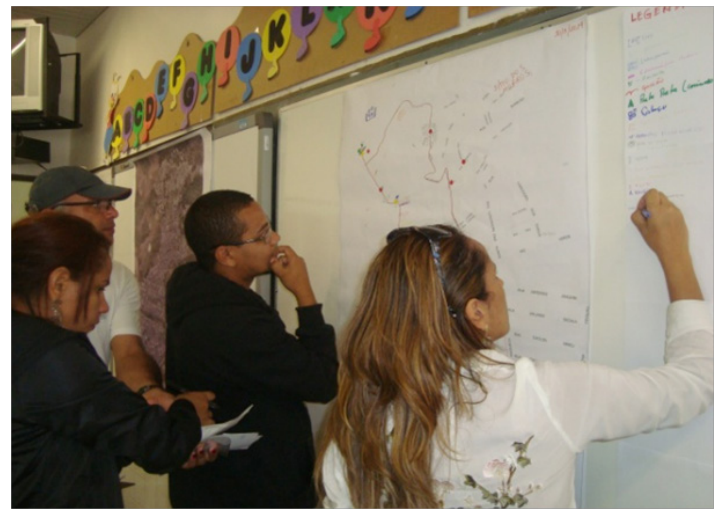

Figure 3. Teachers building a propositional map-synthesis of the site (Soares 2016, Soares \& Santos 2017)

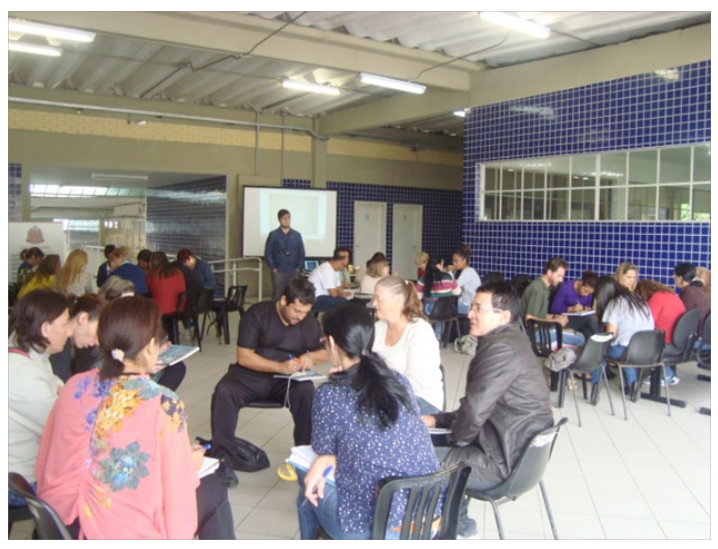

Figure 4. Role-playing Game performed with participating teachers (Soares 2016, Soares \& Santos 2017)

The World-Café objective (Fig. 5.) was to discuss and think about possible collaborative socioenvironmental school proposals that contribute to geoconservation and sustainability through the sharing of knowledge, seeking in search of significant questions and solutions that can emerge from the collective process.

\section{Conclusion}

The continuing education teacher training course proposal introduced in this article was chosen to deal with the complex reality in which the Gold Cycle Geopark Project is inserted.

To do this, it was necessary to take into account three aspects: the political issues related to the territory of the geopark, directly linked to the management of the territory; the educational issues, where the school is the stage for promoting citizenship and socio-environmental protagonism; the public policies issues, guided by the development of a cul- 


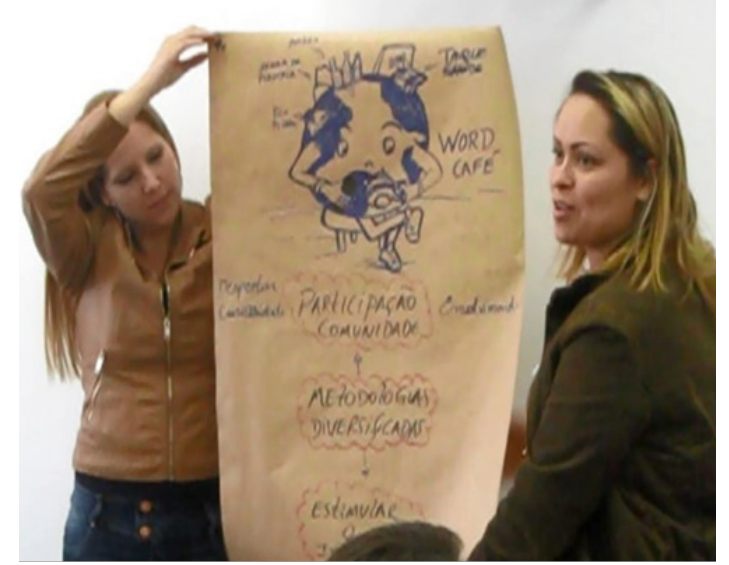

Figure. 5. World-Café performed with participating teachers (Soares 2016, Soares \& Santos 2017)

ture of citizen participation in local socio-environmental issues (Soares 2016; Santos \& Jacobi 2017; Soares \& Santos 2017).

In this context, participatory methodologies, based on Social Learning, had the potential to contribute to the effective participation of the community in actions focused on the promotion of geoconservation, since they can promote a collective transformation of paradigms by putting into practice political involvement of different stakeholders into public polices by means of education practices.

Participatory methodologies, as tools to foster dialogue, promoted the responsibility of all stakeholders involved in the implementation, management, disclosure and protection of the heritage of the Gold Cycle Geopark Project.

The participatory character of the course pointed out some possible collaborative actions among teachers, technicians, community and the tourism secretariat. Among these actions were: events to raise awareness, partnerships and training, income generation, infrastructure development for tourism, and training of junior guides to act directly in the dissemination of information about the heritage of Guarulhos. These actions educate and raise awareness among the community about the possibilities of the territory. The activities developed during the course can also promote local sustainability.

Social Learning has also made possible the promotion of a geoscientific culture and participation, which together, by empowering local citizens through dialogue, contribute to transform the local socio-environmental reality.

\section{Acknowledgements}

Firstly, to the greatly dedicated teachers and students of Guarulhos, who evidenced the enormous potential that public schools have in the construction of multiple didactic-pedagogical knowledge, as a contribution to the promotion of Education for Geoconservation.

To the trainers and partners who participated intensely, each with their knowledge and expertise, for the organization and success of the training course.

To the Coordenação de Aperfeiçoamento de Pessoal de Nível Superior (Capes) for the scholarship awarded, which made it possible to carry out the research based on the course.

\section{References}

Amaral R.R. 2008. Uso do RPG pedagógico para o ensino de Física. Recife: Universidade Federal Rural de Pernambuco. 170p. (Dissert. Mestrado).

Amaral R.R., Bastos H.F.B.N. 2011. O Role-playing Game na sala de aula: uma maneira de desenvolver atividades diferentes simultaneamente. $R e-$ vista Brasileira de Pesquisa em Educação em Ciências, 11(1):103-122.

Brown J., Isaacs D. 2007. O World Café: dando forma ao nosso futuro por meio de conversações significativase estratégicas. São Paulo: Cultrix. 256p.

Brusi D. 1992. Reflexiones en torno a la didáctica de las salidas de campo en geología. Simposio De Enseñanza De La Geología, 7:363-407.

Camargo M.E.S.A. 2006. Jogo de papéis (RPG) em diálogo com a Educação Ambiental: aprendendo a participar da gestão dos recursos hídricos na Região Metropolitana de São Paulo. São Paulo: Instituto de Energia e Ambiente, Universidade de São Paulo. 175p. (Dissert. Mestrado).

Camargo M.E.S.A. 2011. World Café: Método de Diálogo e Criação Coletiva Como Ferramenta de Educação Ambiental. In: Jacobi P.R. org. 2011. Aprendizagem social: diálogos e ferramentas participativas: aprender juntos para cuidar da água. São Paulo: GovAmb, IEE, PROCAM, USP, p. 33-36.

Camargo M.E.S.A. 2015. O World-café e o aprendizado pelo diálogo: limites e possibilidades de um território de sentidos no processo de formação "Diagnóstico socioambiental na APA Embu Verde: Educação Ambiental para a sustentabilidade na bacia do rio Cotia”, Embu das Artes, SP. São Paulo: Fac. Educ., USP. 210p. (Tese Dout.).

Cernesson F. et al. 2005. Learning Together to Manage Together. Improving Participation in Water Management Osnabrück: University of Osnabrück, Institute of Environmental Systems Research. 115p.

Compiani M. (Org.) 2013. Ribeirão Anhumas na Escola: projeto de formação continuada elaborando conhecimentos escolares relacionados à ciência, à socie- 
dade e ao ambiente. Curitiba: Editora CRV. 248p.

Frodeman R. 2010. O raciocínio geológico: a Geologia como uma ciência interpretativa e histórica. Terrce Didatica, 6(2):85-99. URL: https://periodicos.sbu.unicamp.br/ojs/index.php/td/article/ view/8637460/5165.

Jacobi P.R. org. 2011. Aprendizagem social: diálogos e ferramentas participativas: aprender juntos para cuidar da água. São Paulo: GovAmb, IEE, PROCAM, USP. 44p.

Marcatto A. 1996. Saindo do quadro: uma metodologia lúdica e participativa baseada no Role Playing Game. $2^{a}$ ed. São Paulo: Exata Comunicação e Serviços S/C. 185p.

Orion N. 2001. A educação em Ciências da Terra: da teoria à prática-implementação de novas estratégias de ensino em diferentes ambientes de aprendizagem. In: Marques L., Praia J. coords. 2001. Geociências nos currículos básico e secundário. Aveiro: Universidade Aveiro, p. 93-114.

Paschoale C. 1989. Geologia como Semiótica da Natureza. São Paulo: Pontif. Univ. Católica. 138 p. (Dissert. Mestrado).

Pavão A. 2000. A aventura da leitura e da escrita entre mestres de Role-playing Game. $2^{\mathrm{a}}$ ed. São Paulo: Devir. 232p.

Perez-Aguilar A. et al. 2012. Geoparque Ciclo do Ouro, Guarulhos-SP - propostas. In: Schobbenhaus C., Silva C.R. orgs. 2012. Geoparques do Brasil: propostas. Rio de Janeiro: CPRM. p.543-582.

Potapova M.S. 1968. Geologia como uma ciência da natureza. In: Interaction of the sciences in the study of the Earth. Moscou: Progress Publishes.

Riyis M. 2004. Simples: sistema inicial para mestresprofessores lecionarem através de uma estratégia motivadora. São Paulo: Ed. do Autor. 88p.

Santos V.M.N. 2006. Formação de professores para o estudo do ambiente: projetos escolares e a realidade socioambiental local. Campinas: Inst. Geoc., Univ. Est. Campi- nas. 227p. (Tese Dout.).

Santos V.M.N. 2011. Educar no Ambiente: construção do olhar geocientífico e cidadania. São Paulo: Editora Annablume. 178p.

Santos V.M.N., Bacci D.L.C. 2011. Mapeamento Socioambiental para Aprendizagem Social. In: Jacobi P.R. org. 2011. Aprendizagem social: diálogos e ferramentas participativas: aprender juntos para cuidar da água. São Paulo: GovAmb, IEE, PROCAM, USP, p. 61-81.

Santos V.M.N. 2015. Metodologias Participativas como Práticas de Aprendizagem Social para Sustentabilidade $e$ Geoconservação. São Paulo: Instituto de Energia e Ambiente. Universidade de São Paulo (Projeto de pesquisa de pós-doutorado).

Santos V.M.N., Jacobi P.R. 2018. Educação, Ambiente e Aprendizagem Social: metodologias participativas para geoconservação e sustentabilidade. Revista Brasileira de Estudos Pedagógicos, Brasília, v.98, n.249, p.522-539, maio/ago.

Schobbenhaus C., Silva C.R. (orgs). 2012. Geoparques do Brasil: propostas. Rio de Janeiro, CPRM.

Soares D.B., Santos V.M.N. 2014. Educação para Geoconservação e Sustentabilidade na Formação Continuada de Professores no Contexto de um Geoparque Urbano na Região Metropolitana de São Paulo, Brasil. Acta de resúmenes presentados en el II Simposio de Geoparques y Geoturísmo en Chile, Santiago, p. 22-26.

Soares D.B. 2016. Formação Continuada de Professores em Geociências com Metodologias Participativas: contribuições à Educação para Geoconservação. Campinas: Inst. Geoc., Univ. Est. Campinas. 194p. (Dissert. Mestrado).

Soares D.B., Santos V.M.N. 2017. Educação, Ambiente e Aprendizagem Social na Formação de Professores para Geoconservação. Terre, 14(1-2):41-53. 